\title{
STRUKTUR ANATOMI, SIFAT FISIK DAN MEKANIK KAYU PALADO (Aglaia sp.)
}

\author{
(Anatomical Structure, Physical and Mechanical \\ Properties of Aglaia sp.)
}

\author{
Oleh/By : \\ Mody Lempang \& Muhammad Asdar ${ }^{1)}$
}

\begin{abstract}
This research was carried out to identify wood anatomical structure, physical and mechanical properties of palado (Aglaia sp.) wood from natural production forest in Kalukkeu, District of Mamuju, West Sulawesi.

The result showed that palado has white to light yellow colour of sapwood and light brown to grayish brown colour of heartwood; straight grain; rather fine texture; the vessels is few (3 per sq.mm), oval and solitary; simple perforation; rays extremely short, fine and few (height $327 \mu \mathrm{m}$, width $25.52 \mu \mathrm{m}$ and frequencies 5 per sq.mm), parenchyma is diffuse or scanty paratracheal. The fiber length $1.132 \mu \mathrm{m}$ and diameter $25.61 \mu \mathrm{m}$, lumina diameter $17.39 \mu \mathrm{m}$ and wall thickness $1.64 \mu \mathrm{m}$. Air dry moisture content 15.85\%; air dry specific gravity 0.48 and oven dry specifig gravity (density) 0.53; shrinkage from green to air dry condition $2.71 \%$ (radial) and $4.67 \%$ (tangensial); ultimate bending strength 612.72 $\mathrm{kg} / \mathrm{cm}^{2}$ and compression parallel to grain $402.28 \mathrm{~kg} / \mathrm{cm}^{2}$.
\end{abstract}

Keywords: Wood, anatomy, physical property, mechanical property, palado

\begin{abstract}
ABSTRAK
Penelitian ini dilaksanakan untuk mengidentifikasi struktur anatomi, sifat fisik dan sifat mekanik kayu palado (Aglaia sp.) yang diambil dari hutan produksi alam di Kalukku Kabupaten Mamuju, Propinsi Sulawesi Selatan.

Hasil penelitian menunjukkan bahwa palado memiliki kayu gubal berwarna putih sampai krem dan teras berwarna coklat muda sampai coklat kelabu; serat lurus, tekstur agak halus, pori sedikit (3 per. $\mathrm{mm}^{2}$ ) berbentuk lonjong dan tersebar tata baur; perforasi tipe sederhana; jari-jari luar biasa pendek, sempit dan jarang (tinggi $327 \mu \mathrm{m}$; lebar 25,52 $\mu \mathrm{m}$ dan frekuensi 5 per $\mathrm{mm}^{2}$, parenkim tersebar atau baur. Panjang serat $1.132 \mu \mathrm{m}$ dan diameter serat $25,61 \mu \mathrm{m}$; diameter lumen 17,39 $\mu \mathrm{m}$; dan tebal dinding 1,64 $\mu \mathrm{m}$. Kadar air kering udara $15,85 \%$; berat jenis kering udara 0,48 dan berat jenis kering tanur (kerapatan) 0,53; penyusutan kering udara ke kering tanur 2,71\% (radial) dan 4,67\% (tangensial); keteguhan lentur pada batas patah $612,72 \mathrm{~kg} / \mathrm{cm}^{2}$ dan keteguhan tekan sejajar serat $402,28 \mathrm{~kg} / \mathrm{cm}^{2}$.
\end{abstract}

Kata kunci : Kayu, anatomi, sifat fisik, sifat mekanik, palado

\footnotetext{
${ }^{1)}$ Peneliti pada Balai Penelitian dan Pengembangan Kehutanan Sulawesi di Makasar
} 


\section{PENDAHULUAN}

Salah satu karakteristik kayu yang paling penting adalah sifatnya yang dapat diperbaharui. Bahkan mungkin kayu tidak akan habis asal penggunaannya didasari dengan pandangan masa depan dan perencanaan jangka panjang. Semakin berkurangnya sumber bahan bakar fosil, sumber alternatif seperti kayu yang secara terus menerus diperbaharui oleh alam menjadi sangat penting.

Kayu merupakan bahan mentah yang sangat tua, beribu-ribu tahun yang lalu, ketika hutan lebat menutupi kawasan yang luas dipermukaan bumi, orang-orang primitif menggunakan kayu untuk bahan bakar dan perkakas. Namun, di sisi lain kayu merupakan bahan dasar yang sangat moderen. Kubah-kubah kayu yang besar dan perabot-perabot kayu yang indah membuktikan kegunaan dan keindahannya. Bahkan dalam alih bentuk seperti kayu lapis, papan partikel, pulp dan kertas, serat, film, aditif dan banyak produk-produk lain. Sehingga, tidaklah berlebihan jika dikatakan bahwa kayu adalah salah satu produk alam yang sangat penting.

Indonesia memiliki potensi hutan sekitar 4.000 jenis kayu, dan diperkirakan 400 jenis diduga akan memegang peranan penting dikemudian hari. Dari 400 jenis tersebut 258 jenis yang diperdagangkan, paling tidak secara lokal. Sementara sampai tahun 1986 baru sekitar 95 jenis yang telah diteliti sifat dasarnya secara lengkap dan sifat dasar kayu lainnya baru sebagian diteliti (Mandang dan Martawijaya, 1987). Oleh karena itu, penelitian tentang sifat dasar kayu, khususnya kayu kurang dimanfaatkan penting dilakukan.

Kecenderungan pemakaian kayu akan terus meningkat, baik untuk keperluan struktural maupun industri. Hal ini perlu diimbangi dengan pengetahuan jenis kayu, sifat dan cara pengolahan kayu agar kayu dapat digunakan secara efektif dan efisien. Untuk memenuhi kebutuhan kayu yang semakin meningkat dimasa yang akan datang dan untuk memperoleh nilai manfaat kayu yang sebesar-besarnya dari hutan saat ini tidak dapat lagi dipisahkan dari perhatian terhadap pemanfaatan jenis kayu dari jenis pohon kurang dikenal. Namun sebelum menggunakan kayu dari jenis pohon kurang dikenal untuk tujuan tertentu, terlebih dulu perlu dilakukan penelitian mengenai sifat dasar dan kemungkinan pemanfaatan kayu dari jenis pohon tersebut.

Ketepatan pemilihan jenis kayu untuk sesuatu pemakaian memerlukan pengetahuan tentang sifat dasarnya. Sifat dasar tersebut, diantaranya berat jenis, kekuatan dan stabilitas dimensi. Faktor ini diengaruhi oleh sifat anatomi kayu. Sebagai contoh pohon yang membentuk kayu dengan berat jenis tinggi dipengaruhi antara lain oleh dinding sel yang tebal dan zat ekstaktif akan paling bernilai bagi pengolah produk-produk kayu gergajian struktural. Sedangkan jenis pohon yang menghasilkan kayu dengan berat jenis rendah dipengaruhi oleh rongga sel yang besar, jumlah dan ukuran pori, jenis ini cocok sebagai bahan baku pembuatan pulp dan kertas. Jadi, sifat dasar kayu ini penting dipahami agar didalam proses pengolahan, pengangkutan, maupun penggunaannya dapat dilakukan secara saksama sehingga tidak terjadi pengorbanan bahan, waktu, tenaga maupun biaya yang sia-sia.

Tulisan ini adalah hasil penelitian struktur anatomi, sifat fisik dan mekanik kayu palado sehingga dapat ditetapkan kelas dimensi serat berdasarkan nilai turunan serat, kelas kuat berdasarkan sifat fisik dan mekanik dan rekomendasi penggunaannya. 


\section{BAHAN DAN METODE}

\section{A. Bahan}

Bahan yang digunakan sebagai contoh uji dalam penelitian ini adalah jenis kayu Sulawesi yaitu palado (Aglaia sp.) sebanyak tiga pohon. Penelitian dilaksanakan dari bulan September sampai bulan Desember 2004. Contoh uji diambil dari hutan produksi alam di Kalukku, Kabupaten Mamuju Propinsi Sulawesi Selatan. Pengamatan struktur anatomi dan pengujian sifat fisik dilaksanakan pada laboratorium Balai Penelitian dan Pengembangan Kehutanan Sulawesi di Makassar, sementara pengujian sifat mekanik dilaksanakan di laboratorium Struktur Bahan Fakultas Teknik Jurusan Sipil Universitas Hasanuddin.

\section{B. Metode}

Pengamatan struktur anatomi kayu meliputi ciri umum (makroskopis) dan ciri anatomi (mikroskopis). Ciri umum kayu diamati pada contoh kayu utuh maupun yang telah diketam. Pertelaannya dilakukan menurut yang disusun oleh Martawijaya dan Kartasudjana (1977), yaitu meliputi warna kayu, tekstur, arah serat, kilap, kesan raba dan gambar. Ciri anatomi diamati pada preparat maserasi dan sayatan pada bidang lintang, radial dan tangensial yang telah diwarnai dengan safranin menurut metode Sass (1958). Ciri yang diamati meliputi dimensi serat, dimensi pembuluh, susunan dan sebaran pembuluh, susunan parenkim, susunan dan bentuk jari-jari, adanya saluran interselular, silika, dan lain-lain sesuai dengan IAWA list (IAWA, 1989).

Pengujian sifat fisik dan mekanik dilakukan dengan mengikuti standar JIS dalam Ginoga (1974). Pengujian sifat fisik kayu meliputi kadar air, berat jenis dan penyusutan mengikuti JIS Z 2101, Z 2102 dan Z 2103. Pengujian sifat mekanik meliputi keteguhan lentur statik, keteguhan tarik sejajar serat, keteguhan tekan sejajar serat dan keteguhan tekan tegak lurus serat mengikuti JIS Z 2113, Z 2112 dan Z 2111.

Penelitian ini dilaksanakan dengan menggunakan rancangan percobaan tersarang dalam pola acak lengkap dengan dua faktor dan lima kali ulangan. Faktor utama (A) adalah pohon yang digunakan sebagai sampel yang terdiri dari tiga taraf, yaitu : pohon pertama (a1), pohon kedua (a2) dan pohon ketiga (a3). Faktor kedua (B) sebagai faktor tersarang adalah posisi ketinggian dalam batang terdiri dari tiga taraf, yaitu: pangkal batang pohon (b1), tengah batang pohon (a2) dan ujung batang pohon (a3). Dengan demikian terdapat 9 satuan percobaan dan setiap satuan percobaan diulang lima kali.

\section{Analisis Data}

Dalam pengolahan data, hasil pengujian/pengukuran sifat kayu, satuannya dinyatakan berdasarkan parameter yang diuji/diukur. Nilai yang diperoleh dari hasil pengamatan sifat anatomi ditabulasi dan dianalisis secara deskriptif, sedangkan untuk mengetahui keragaman sifat fisik dan mekanik kayu pada berbagai posisi ketinggian dalam batang, data hasil pengujian kemudian dianalisis dengan menggunakan model analisis dua faktor dengan pola tersarang. Menurut Sudjana (1989), model matematis dari desain eksperimen tersarang adalah: $Y i j k=u+A i+B j(i)+E k(i j)$ 


\section{HASIL DAN PEMBAHASAN}

\section{A. Struktur Anatomi}

Kayu gubal berwarna putih sampai krem, jelas batasnya dengan kayu teras yang berwarna coklat muda sampai coklat kelabu, berserat lurus, tekstur agak halus, agak kesat dan agak kusam. Kayu yang diteliti berdiameter rata-rata $38 \mathrm{~cm}$ dan memiliki kayu gubal yang lebar. Diameter kayu teras hanya mencapai sekitar $18 \mathrm{~cm}$ atau sekitar $22 \%$ dari volume total kayu.

Pori berbentuk lonjong, tersebar tata baur, agak kecil dengan diameter rata-rata 143.20 $\mu \mathrm{m}(82,5$ - 187,5 $\mu \mathrm{m}$, standar deviasi 28,47), sebagian besar soliter dan sebagian bergabung 2-3 ke arah radial, frekuensi jarang yaitu rata-rata 3 pori per $\mathrm{mm}^{2}\left(1-4\right.$ per $\mathrm{mm}^{2}$, stdv 0,67$)$ dan perforasi bertipe sederhana. Jari-jari sempit dengan lebar rata-rata 25,52 $\mu \mathrm{m}(12,5$ - $45 \mu \mathrm{m}$, stdv 6,26 ), luar biasa pendek dengan tinggi $327 \mu \mathrm{m}(120-700 \mu \mathrm{m}$, stdv 94,3), jumlahnya jarang dengan frekuensi 4,89 per $\mathrm{mm}(2-8$ per $\mathrm{mm}$, stdv 1,68), bertipe heterogen terdiri atas sel tegak dan sel baring serta berseri 2-3.

Parenkim tersebar atau baur (difus) dan sebagian selubung tidak lengkap. Kayu ini memiliki saluran interselluler radial.

Panjang serat sekitar $1.132 \mu \mathrm{m}(674-1.850 \mu \mathrm{m}$, stdv 199,77), diameter lumen rata-rata $17,39 \mu \mathrm{m}(5-36 \mu \mathrm{m}, \mathrm{stdv} 4,87)$, diameter serat 25,61 $\mu \mathrm{m}(13-45 \mu \mathrm{m}$, stdv 5,39) dan tebal dinding 1,64 $\mu \mathrm{m}(1-4 \mu \mathrm{m}$, stdv 0,5). Nilai turunan serat berdasarkan Departemen Pertanian (1976): Panjang serat tergolong kelas III, runkel ratio (kelas I), felting power (kelas III), Muhlstep Ratio (kelas II) dan coefficient of regidity (kelas I). Secara keseluruhan dimensi serat kayu palado tergolong kelas II untuk bahan baku pulp dan kertas yang berarti bahwa serat kayu ini mudah dipipihkan sehingga akan menghasilkan kertas yang berkualitas baik.

\section{B. Sifat Fisik}

Pengukuran sifat fisik kayu palado dilakukan pada kondisi kering udara dan kering tanur. Nilai rata-rata hasil pengukuran sifat fisik dapat dilihat pada Tabel 1 berikut ini :

\section{Tabel 1. Rata-rata sifat fisik kayu palado (Aglaia sp.)}

Table 1. Average of physical properties of palado (Aglaia sp.) wood

\begin{tabular}{|c|c|c|c|}
\hline No. & $\begin{array}{c}\text { Sifat Fisik } \\
\text { (Physical properties) }\end{array}$ & $\begin{array}{c}\text { Satuan } \\
\text { (Unit) }\end{array}$ & $\begin{array}{l}\text { Rata-rata } \\
\text { (Average) }\end{array}$ \\
\hline 1. & Kadar air kering udara (Air dry moisture content) & $\%$ & 15,85 \\
\hline 2. & Berat jenis kering udara (Air dry specific gravity) & - & 0,48 \\
\hline 3. & Berat jenis kering tanur (Oven dry specific gravity) & - & 0,53 \\
\hline 4. & $\begin{array}{l}\text { Penyusutan dari kering udara ke kering tanur: } \\
\text { (Shrinkage from green to air } d r y \text { ) }\end{array}$ & & \\
\hline & Radial & $\%$ & 2,71 \\
\hline & Tangensial & $\%$ & 4,67 \\
\hline
\end{tabular}


Hasil pengujian sifat fisik seperti pada Tabel 1 di atas menunjukkan bahwa kadar air kering udara rata-rata 15,85\%. Berat jenis kering udara rata-rata 0,48 dan berat jenis kering tanur (kerapatan) rata-rata 0,53. Berdasarkan klasifikasi kayu menurut Dumanauw (1982), maka kayu tersebut termasuk kayu ringan karena mempunyai berat jenis kering udara $<0,60$, sementara berdasarkan klasifikasi kelas kuat kayu Indonesia oleh Den Berger (1923) dalam Darwo (1994), kayu palado tergolong kayu kelas kuat III (BJ antara 0,40 - 0,60). Kayu palado tergolong kayu ringan dengan penyusutan dari keadaan kering udara ke kering tanur rata-rata 2,71\% (Radial) dan 4,67\% (Tangensial) dan ini menunjukkan bahwa kayu palado tergolong penyusutan sangat tinggi. Perbandingan penyusutan tangensial dan radial (T/R) sebesar 1,72 menunjukkan bahwa kayu tersebut memiliki kestabilan dimensi yang cukup rendah. Phansin dan De Zeeuw (1980) mengemukakan bahwa nilai T/R yang makin mendekati 1,00 berarti stabil. Kayu palado dalam bentuk papan tebal yang dikering udarakan dibawah atap berubah bentuk (melengkung) dan cacat retak yang cukup berat. Dengan demikian maka pengeringan kayu tersebut harus dilakukan dengan hati-hati. Perlu pertimbangan yang kuat dalam menggunakan kayu palado bila penggunaannya membutuhkan nilai kestabilan dimensi yang tinggi, misalnya untuk mebel dan barang kerajinan.

Untuk mengetahui pengaruh posisi ketinggian dalam batang terhadap nilai sifat fisik kayu, dilakukan analisis keragaman terhadap nilai rata-rata hasil perhitungan. Sidik ragam nilai sifat fisik kayu palado disajikan pada Lampiran 1. Hasil sidik ragam menunjukkan bahwa, posisi ketinggian dalam batang berpengaruh nyata terhadap nilai berat jenis kering tanur (kerapatan), akan tetapi tidak berpengaruh nyata terhadap nilai kadar air kering udara, berat jenis kering udara dan penyusutan kering udara ke kering tanur baik pada arah radial maupun tangensial. Selanjutnya untuk mengetahui pada posisi mana saja dalam batang nilai-nilai sifat fisik kayu berbeda nyata, maka dilakukan uji beda nyata jujur (BNJ). Hasil uji BNJ pengaruh posisi ketinggian dalam batang terhadap nilai sifat fisik kayu disajikan dalam Tabel 2 di bawah ini :

Tabel 2. Rekapitulasi hasil uji BNJ (beda nyata jujur) sifat fisik kayu palado (Aglaia sp.) pada berbagai ketinggian dalam batang.

Table 2. Recapitulation on HSD (bonestly significant difference) test results of physical properties of palado (Aglaia sp.) On various beight position in the trunk.

\begin{tabular}{|c|c|c|c|c|c|}
\hline \multirow{2}{*}{ No. } & \multirow{2}{*}{$\begin{array}{l}\text { Sifat Fisik } \\
\text { (Physical property) }\end{array}$} & \multirow{2}{*}{$\begin{array}{c}\text { Satuan } \\
\text { (Unit) }\end{array}$} & \multicolumn{3}{|c|}{$\begin{array}{l}\text { Ketinggian dalam batng } \\
\text { (Level position in trunk.) }\end{array}$} \\
\hline & & & $\begin{array}{l}\text { Pangkal } \\
\text { (Button) }\end{array}$ & $\begin{array}{l}\text { Tengah } \\
\text { (Middle) }\end{array}$ & $\begin{array}{l}\text { Ujung } \\
\text { (Top) }\end{array}$ \\
\hline 1. & $\begin{array}{l}\text { Berat jenis kering tanur } \\
\text { (Oven dry specific gravity) }\end{array}$ & - & 0,54 & $\underline{0,53}$ & 0,52 \\
\hline
\end{tabular}

Keterangan (Remarks) : Nilai-nilai pada baris yang diberi garis bawah berbeda tidak nyata (Values in the row with underlines are not significantly different). 
Tabel 2 menunjukkan bahwa nilai berat jenis kering udara pada bagian pangkal batang berbeda nyata dengan bagian tengah dan ujung. Sedangkan bagian tengah berbeda tidak nyata dengan bagian ujung.

\section{Sifat Mekanik}

Hasil pengujian sifat mekanik kayu palado yang dilakukan dalam kondisi kering udara disajikan pada Tabel 3 berikutini:

Tabel 3. Rata-rata sifat mekanik kayu palado (Aglaia sp.) Table 3. Average of mechanical properties of palado (Aglaia sp.) Wood

\begin{tabular}{|c|c|c|c|}
\hline No. & $\begin{array}{c}\text { Sifat Mekanik } \\
\text { (Mechanical properties) }\end{array}$ & $\begin{array}{l}\text { Satuan } \\
\text { (Unit) }\end{array}$ & $\begin{array}{l}\text { Rata-rata } \\
\text { (Mean) }\end{array}$ \\
\hline 1. & $\begin{array}{l}\text { Keteguhan lentur pada batas proporsi } \\
\text { (Bending strength until proporsional limit) }\end{array}$ & $\mathrm{kg} / \mathrm{cm}^{2}$ & 394,56 \\
\hline 2. & $\begin{array}{l}\text { Keteguhan lentur pada batas patah } \\
\text { (Absolut bending strength) }\end{array}$ & $\mathrm{kg} / \mathrm{cm}^{2}$ & 612,72 \\
\hline 3. & $\begin{array}{l}\text { Modulus elastisitas } \\
\text { (Modulus of elasticity) }\end{array}$ & $\mathrm{kg} / \mathrm{cm}^{2}$ & $9.892,26$ \\
\hline 4. & $\begin{array}{l}\text { Keteguhan tarik sejajar serat } \\
\text { (Tension parallel to grain) }\end{array}$ & $\mathrm{kg} / \mathrm{cm}^{2}$ & 787,48 \\
\hline 5. & $\begin{array}{l}\text { Keteguhan tekan sejajar serat } \\
\text { (Compression parallel to grain) }\end{array}$ & $\mathrm{kg} / \mathrm{cm}^{2}$ & 402,28 \\
\hline 6. & $\begin{array}{l}\text { Keteguhan tekan tegak lurus serat } \\
\text { (Compression perpendicular to grain) }\end{array}$ & $\mathrm{kg} / \mathrm{cm}^{2}$ & 83,80 \\
\hline
\end{tabular}

Pada umumnya klasifikasi kekuatan kayu di Indonesia didasarkan pada keteguhan lentur pada batas patah dan keteguhan tekan sejajar serat. Sifat-sifat mekanik lainnya juga penting diketahui dalam hubungannya dengan pengolahan dan pemanfaatan kayu untuk keperluan tertentu. Berdasarkan nilai keteguhan lentur pada batas patah $\left(612,72 \mathrm{~kg} / \mathrm{cm}^{2}\right)$ dan keteguhan tekan sejajar serat $\left(402,28 \mathrm{~kg} / \mathrm{cm}^{2}\right)$ kayu palado tergolong kelas kuat III.

Untuk mengetahui pengaruh ketinggian pada batang terhadap sifat mekanik, dilakukan analisis keragaman yang sidik ragamnya disajikan pada Lampiran 2. Hasil analisis keragaman menunjukkan bahwa posisi ketinggian dalam batang berpengaruh sangat nyata terhadap nilai keteguhan lentur statis pada proporsi, lentur pada batas patah, keteguhan tarik sejajar serat dan keteguhan tekan sejajar serat, tetapi berpengaruh tidak nyata terhadap nilai modulus elastis dan keteguhan tekan tegak lurus serat. Selanjutnya untuk mengetahui pada posisi mana saja dalam batang yang nilai sifat mekaniknya berbeda nyata, maka dilakukan uji beda nyata jujur (BNJ). Hasil uji BNJ pengaruh posisi ketinggian dalam batang terhadap nilai sifat mekanik disajikan dalam Tabel 4 berikut ini : 
Tabe14. Rekapitulasi hasil uji BNJ (beda nyata jujur) sifat mekanik kayu palado (Aglaia sp.) pada berbagai ketinggian dalam batang.

Table 4. Recapitulation on HSD (bonestly significant difference) test results of mechanical properties of palado (Aglaia sp.) on various beight in the trunk

\begin{tabular}{|c|c|c|c|c|c|}
\hline \multirow{2}{*}{ No. } & \multirow{2}{*}{$\begin{array}{c}\text { Sifat Mekanik } \\
\text { (Mechanical properties) }\end{array}$} & \multirow{2}{*}{$\begin{array}{l}\text { Satuan } \\
\text { (Unit) }\end{array}$} & \multicolumn{3}{|c|}{$\begin{array}{l}\text { Ketinggian dalam batng } \\
\text { (Level position in trunk.) }\end{array}$} \\
\hline & & & $\begin{array}{l}\text { Pangkal } \\
\text { (Button) }\end{array}$ & $\begin{array}{l}\text { Tengah } \\
\text { (Middle) }\end{array}$ & $\begin{array}{l}\text { Ujung } \\
(\text { Top })\end{array}$ \\
\hline 1. & $\begin{array}{l}\text { Keteguhan lentur pada batas proporsi } \\
\text { (Bending strenoth until proporsional limit) }\end{array}$ & $\mathrm{kg} / \mathrm{cm}^{2}$ & 413,44 & 400,49 & 369,73 \\
\hline 2. & $\begin{array}{l}\text { Keteguhan lentur pada batas patah } \\
\text { (Absolut bending strength) }\end{array}$ & $\mathrm{kg} / \mathrm{cm}^{2}$ & 660,58 & 607,02 & 570,56 \\
\hline 3. & $\begin{array}{l}\text { Keteguhan tarik sejajar serat } \\
\text { (Tension parallel to grain) }\end{array}$ & $\mathrm{kg} / \mathrm{cm}^{2}$ & 869,82 & 797,07 & 695,55 \\
\hline 4. & $\begin{array}{l}\text { Keteguhan tekan sejajar serat } \\
\text { (Compression parallel to grain) }\end{array}$ & $\mathrm{kg} / \mathrm{cm}^{2}$ & 421,36 & 393,10 & 386,27 \\
\hline
\end{tabular}

Keterangan (Remarks) : Nilai-nilai pada baris yang diberi garis bawah berbeda tidak nyata (Values in the row with underlines are not significantly different).

Pada Tabel 4 hasil uji BNJ pada taraf nyata 5\% menunjukkan bahwa nilai keteguhan lentur pada batas proporsi, keteguhan lentur pada batas patah, keteguhan tarik sejajar serat dan keteguhan tekan sejajar serat pada bagian pangkal batang berbeda nyata dengan bagian ujung tetapi berbeda tidak nyata dengan bagian tengah batang. Sedangkan bagian tengah berbeda tidak nyata dengan bagian ujung.

\section{Kegunaan}

Secara keseluruhan dimensi serat kayu palado tergolong kelas II untuk bahan baku pulp dan kertas. Oleh karena serat kayu ini mudah dipipihkan, sehingga akan menghasilkan kertas yang berkualitas baik. Ditinjau dari kelas kuat kayu, palado tergolong kelas kuat III, maka kayu ini dapat digunakan sebagai bahan bangunan yang tidak menerima beban yang berat (kaso, reng, dinding, lis dan plafon). Disamping itu, palado tergolong kayu ringan, bertekstur agak halus, mudah dikerjakan (digergaji, dibor, diserut dan dibentuk) dengan hasil yang baik sehingga dapat digunakan sebagai bahan pembuatan moulding, furniture, kerajinan dan pallet. 


\section{KESIMPULAN DAN SARAN}

1. Kayu palado memiliki kayu gubal berwarna putih sampai krem, jelas batasnya dengan kayu teras yang berwarna coklat muda sampai coklat kelabu, berserat lurus, tekstur agak halus, agak kesat dan agak kusam.

2. Panjang serat tergolong kelas III, runkel ratio (kelas I), felting power (kelas III), Muhlstep Ratio (kelas II) dan coefficient of regidity (kelas I). Secara keseluruhan dimensi serat kayu palado tergolong kelas II untuk bahan baku pulp dan kertas.

3. Kadar air kering udara, berat jenis kering udara, dan penyusutan radial dan tangensial dari kering udara ke kering tanur kayu palado relatif sama pada berbagai ketinggian dalam batang, sedangkan berat jenis kering tanur berbeda nyata pada posisi ketinggian dalam batang. Kadar air kering udara rata-rata $15,85 \%$, berat jenis kering udara rata-rata 0,48 dan berat jenis kering tanur rata-rata 0,53 serta penyusutan dari kering udara ke kering tanur pada arah radial rata-rata $2,71 \%$ dan pada arah tangensial rata-rata 4,67\%.

4. Posisi ketinggian dalam batang berpengaruh nyata terhadap keteguhan lentur pada batas proporsi, keteguhan lentur pada batas patah, keteguhan tarik sejajar serat dan keteguhan tekan sejajar serat, tetapi tidak berpengaruh nyata pada nilai modulus elastisitas dan keteguhan tekan tegak lurus serat.

5. Berdasarkan nilai berat jenis kering udara $(0,48)$, keteguhan lentur pada batas patah $\left(612,72 \mathrm{~kg} / \mathrm{m}^{2}\right)$ dan keteguhan tekan sejajar serat $\left(402,28 \mathrm{~kg} / \mathrm{cm}^{2}\right)$, palado tergolong kayu kelas kuat III.

6. Kayu palado tergolong kayu kelas kuat III dapat digunakan untuk bahan konstruksi, tetapi terbatas pada bagian-bagian yang tidak memikul beban berat (kaso, reng, dinding, lis dan plafon). Di samping itu, kayu palado dapat digunakan untuk moulding, vinir, furniture, kerajinan, pallet, dan baik untuk bahan baku pulp dan kertas.

\section{DAFTAR PUSTAKA}

Darwo. 1994. Sifat fisis, mekanis dan kelas kuat kelompok jenis kayu Borneo berdasarkan contoh kecil bebas cacat. Buletin Penelitian Kehutanan 10 (2): 107-126. Badan Penelitian dan Pengembangan Kehutanan. Bogor.

Departemen Pertanian. 1976. Vademecum Kehutanan Indonesia. Direktorat Jenderal Kehutanan. Jakarta.

Dumanau, J. 1982. Mengenal kayu. Gramedia. Jakarta

Ginoga, B. 1974. Pengujian sifat fisik dan mekanik kayu di Jepang. Lembaga Penelitian Hasil Hutan. Direktorat Jenderal Kehutanan, Departemen Pertanian. Bogor.

IAWA Committee. 1989. IAWA List of miscroscopic features for hardwood identification. IAWA Bull. N.s 10 (3) : 219-332. Leiden, Netherlands.

Mandang Y. I. dan A. Martawijaya. 1987. Pemanfaatan jenis kayu kurang dikenal. Prosiding Diskusi Pemanfaatan Kayu Kurang Dikenal. Badan Penelitian dan Pengembangan Kehutanan. Bogor. 
Martawijaya, A., dan I. Kartasujana. 1977. Ciri umum, sifat dan kegunaan jenis-jenis kayu Indonesia. Publikasi Khusus Lembaga Penelitian Hasil Hutan, No. 41. Badan Penelitian dan Pengembangan Pertanian, Departemen Pertanian. Bogor.

Panshin, A. J and de Zeeuw. 1980. Texbook of Wood Technology. 14th ed. McGraw-Hill Book Co. New York.

Sass, J. 1958. Botanical Microtechnique. 3rd. Ed. The Iowa State University Press, Ames, Iowa, USA. Pp. 3-77.

Sudjana. 1989. Desain dan Analisis Eksperimen. Edisi ke III. Penerbit Tarsito. Bandung. 
Lampiran 1. Rekapitulasi sidik ragam sifat fisik Appendix 1. Recapitulation on analysis of variance of physical properties

\begin{tabular}{|c|c|c|c|c|c|}
\hline \multirow{2}{*}{$\begin{array}{c}\text { Sifat fisik } \\
\text { (Physical properties) }\end{array}$} & \multirow{2}{*}{$\begin{array}{c}\text { Sumber } \\
\text { keragaman } \\
\text { (Source of variance) }\end{array}$} & \multirow{2}{*}{$\begin{array}{l}\text { Derajat bebas } \\
\text { (Degree of } \\
\text { freedom) }\end{array}$} & \multirow{2}{*}{$\begin{array}{l}\text { F.hitung } \\
\text { (F. Calc.) }\end{array}$} & \multicolumn{2}{|c|}{$\begin{array}{l}\text { F.table } \\
\text { (F. table })\end{array}$} \\
\hline & & & & 0,05 & 0,01 \\
\hline Kadar air kering udara & Pohon (Tree) & 2 & $2,5417 \mathrm{tn}$ & 5,1400 & 10,9200 \\
\hline (Air dry moisture content) & $\begin{array}{l}\text { Bagian batang } \\
\text { (Level position in }\end{array}$ & 6 & $0,6483 \mathrm{tn}$ & 2,3720 & 3,3620 \\
\hline Berat jenis kering udara & trunk) & 2 & 0,7143 tn & & \\
\hline (Air dry specific gravity) & $\begin{array}{l}\text { Pohon } \\
\text { Bagian batang }\end{array}$ & 6 & 0,6483 tn & & \\
\hline Berat jenis kering tanur & & 2 & $0,5181 \mathrm{tn}$ & & \\
\hline (Oven dry specific gravity) & $\begin{array}{l}\text { Pohon } \\
\text { Bagian batang }\end{array}$ & 6 & $2,7700 *$ & & \\
\hline Penyusutan radial dari & o & 2 & 3,8562 tn & & \\
\hline $\begin{array}{l}\text { kering udara ke kering tanur } \\
\text { (Shrinkage fromair dry to oven } \\
\text { dry in radial direction) }\end{array}$ & $\begin{array}{l}\text { Pohon } \\
\text { Bagian batang }\end{array}$ & 6 & 2,2103 tn & & \\
\hline $\begin{array}{l}\text { Penyusutan tangensial dari } \\
\text { kering udara ke kering tanur } \\
\text { (Shrinkage fromair dry to oven } \\
\text { dry in tangensial direction) }\end{array}$ & $\begin{array}{l}\text { Pohon } \\
\text { Bagian batang }\end{array}$ & $\begin{array}{l}2 \\
6\end{array}$ & $\begin{array}{l}1,2988 \mathrm{tn} \\
1,7720 \mathrm{tn}\end{array}$ & & \\
\hline
\end{tabular}


Lampiran 2. Rekapitulasi sidik ragam sifat mekanik Appendix 2. Recapitulation on analysis of variance of mechanical properties

\begin{tabular}{|c|c|c|c|c|c|}
\hline \multirow[t]{2}{*}{$\begin{array}{c}\text { Sifat mekanik } \\
\text { (Mechanical properties) }\end{array}$} & \multirow{2}{*}{$\begin{array}{c}\text { Sumber } \\
\text { keragaman } \\
\text { (Source of variance) }\end{array}$} & \multirow{2}{*}{$\begin{array}{l}\text { Derajat bebas } \\
\text { (Degree of } \\
\text { freedom) }\end{array}$} & \multirow[t]{2}{*}{$\begin{array}{l}\text { F.hitung } \\
\text { (F. Calc. })\end{array}$} & \multicolumn{2}{|c|}{$\begin{array}{l}\text { F.table } \\
(\text { F. table })\end{array}$} \\
\hline & & & & 0,05 & 0,01 \\
\hline Keteguhan lentur pada & Pohon (Tree) & 2 & 1,6489 tn & 5,1400 & 10,9200 \\
\hline $\begin{array}{l}\text { batas proporsi } \\
\text { (Bending strength until } \\
\text { proporsional limit) }\end{array}$ & $\begin{array}{l}\text { Bagian batang } \\
\text { (Level position in } \\
\text { trunk) }\end{array}$ & 6 & $4,0661 * *$ & 2,3720 & 3,3620 \\
\hline Keteguhan lentur pada & Pohon & 2 & $1,3600 \mathrm{tn}$ & & \\
\hline $\begin{array}{l}\text { batas patah } \\
\text { (Absolut bending strength) }\end{array}$ & Bagian batang & 6 & $2,7923 *$ & & \\
\hline Modulus elastisitas & Pohon & 2 & $1,7851 \mathrm{tn}$ & & \\
\hline (Modulus of elasticit)) & Bagian batang & 6 & 1,1508 tn & & \\
\hline Keteguhan tarik sejajar serat & Pohon & 2 & $2,2198 \mathrm{tn}$ & & \\
\hline (Tension parallel to grain) & Bagian batang & 6 & $2,8036 *$ & & \\
\hline Keteguhan tekan sejajar & Pohon & 2 & $0,2616 \mathrm{tn}$ & & \\
\hline $\begin{array}{l}\text { serat } \\
\text { (Compression parallel to grain) }\end{array}$ & Bagian batang & 6 & $3,7906 * *$ & & \\
\hline Keteguhan tekan tegak lurus & Pohon & 2 & 1,0072 tn & & \\
\hline $\begin{array}{l}\text { serat } \\
\text { (Compression perpendicular } \\
\text { to grain) }\end{array}$ & Bagian batang & 6 & $0,2154 \mathrm{tn}$ & & \\
\hline
\end{tabular}

